\title{
Paraphyly of the genus Boehmeria (Urticaceae): a response to Liang et al.'Relationships among Chinese Boehmeria species and the evolution of various clade'
}

\author{
Alexandre K. Monro ${ }^{1} \cdot$ Steven Dodsworth ${ }^{2}(1) \cdot$ Long-Fei Fu $^{3} \cdot$ Ib Friis $^{4} \cdot$ Christine M. Wilmot-Dear $^{1} \cdot$ Olivier Maurin $^{5}$
}

Received: 20 November 2020 / Accepted: 6 December 2020 / Published online: 19 December 2020

(c) The Author(s) 2020

\begin{abstract}
Boehmeria, as currently circumscribed, comprises 52 species and has a pantropical distribution. Liang et al. propose a sectional classification of Boehmeria based on the phylogenetic analysis of SNP data for 20 species and an additional 10 subspecific taxa of these at the rank of variety or form. They restrict their sampling to species documented in China. We found many shortcomings in the sampling and analyses which we feel have resulted in a misleading phylogeny for the genus and the economically important fibre-plant, Boehmeria nivea. By sampling only Chinese species of this genus for their in-group and using a single distantly related outgroup, Liang et al. have failed to capture the diversity of the genus and so erroneously concluded that it forms a monophyletic group. Previous published research clearly demonstrates that Boehmeria is paraphyletic and polyphyletic, comprising at least four monophyletic groupings most closely related to several genera within the Boehmerieae. For these reasons, the sections that Liang et al. (Ind Crops Prod 148:112092, 2020. https://doi. org/10.1016/j.indcrop.2020.112092) propose for Boehmeria are not effective tools for its classification. The important fibreplant, Boehmeria nivea, should therefore not be considered as part of the genus Boehmeria for the purposes of crop breeding, but as sister to Archiboehmeria. Breeding programmes for ramie should therefore focus on populations and germplasm of Archiboehmeria atrata. We conclude that poor taxon sampling, overlooking relevant molecular and taxonomic literature, internal conflict within their SNP data and the overinterpretation of low support values has resulted in the erroneous conclusion that Boehmeria represents a monophyletic or 'natural' genus.
\end{abstract}

Keywords Monophyly $\cdot$ Paraphyly $\cdot$ Ramie $\cdot$ Systematics $\cdot$ Taxon sampling $\cdot$ Urtica $\cdot$ Urticaceae

Handling Editor: Martin A. Lysak.

Alexandre K. Monro

a.monro@kew.org

$\triangle$ Steven Dodsworth

steven.dodsworth@beds.ac.uk

1 Kew, Identification and Naming Department, Royal Botanic Gardens, Kew, Richmond TW9 3AE, UK

2 School of Life Sciences, University of Bedfordshire, Luton LU1 3JU, UK

3 Guangxi Key Laboratory of Plant Conservation and Restoration Ecology in Karst Terrain, Guangxi Institute of Botany, Guangxi Zhuang Autonomous Region and Chinese Academy of Sciences, Guilin, China

4 Natural History Museum of Denmark, Universitetparken 15, 2100 Copenhagen $\varnothing$, Denmark

5 Kew, Plant and Fungal Trees of Life (PAFTOL) Team, Royal Botanic Gardens, Kew, Richmond TW9 3AE, UK
Boehmeria Jacq., as currently circumscribed (Wilmot-Dear \& Friis 2013), comprises 52 species and has a pantropical distribution (Plants of the World Online 2020). Whilst the greatest diversity of species occurs in Asia, 14 species are known from the Americas (Wilmot-Dear \& Friis 1996, 2013) including the type of the genus, B. ramiflora Jacq., which is native to Central America and north-western South America (Plants of the World Online 2020).

Boehmeria includes the species of greatest economic value within the nettle family (Urticaceae), $B$. nivea, known as 'ramie'. Ramie is presumed native to China where it has been in cultivation for over 3000 years (Chen et al. 2003). Boehmeria nivea was originally described in the nettle genus Urtica by Linnaeus (1753) before being transferred to the genus Boehmeria by Gaudichaud-Baupré (1830). In (1891) Kuntze transferred the species to the genus Ramium but in doing so generated an illegitimate homonym and in the most 
recent revision of the genus (Wilmot-Dear \& Friis 2013), it remains a species of Boehmeria.

Within a systematic framework, subgeneric classifications, such as sections or subgenera, provide a means of recognizing major evolutionary lineages that do not warrant generic rank. Identifying such lineages provides a framework for testing evolutionary hypotheses and in designing plant breeding programmes (Zhang et al. 1998). Indeed, Liang et al. (2020), as justification for their study, state that, 'Boehmeria is the most important natural germplasm bank for deriving commercially viable ramie cultivars'. It is therefore crucial to their study that Boehmeria nivea can be assigned to the genus Boehmeria. If not, then in designing a breeding programme potentially important sources of germplasm may be overlooked.

Within systematic biology, it is implicit that the genus and sections should represent monophyletic groups. Previous phylogenetic studies based on the analysis of chloroplast, nuclear ribosomal and low-copy nuclear DNA have strongly suggested that Boehmeria does not form a monophyletic group (Fig. 1 in Wu et al. 2013; Fig S1 in Wu et al. 2018). Within these studies, Boehmeria is recovered as two or four monophyletic groupings most closely related to other genera in the Boehmerieae tribe of the Urticaceae. These include Boehmeria nivea, which is recovered as most closely related to Archiboehmeria, with strong support, whilst the core of Chinese species were recovered as sister to Cypholophus, with moderate to strong support and the Latin American species as sister to Cypholophus + Asian Boehmeria with strong support, and Boehmeria depauperata as sister to Latin American Boehmeria + Cypholophus + core of Asian Boehmeria (Fig S1 in Wu et al. 2018). This strongly suggests that Boehmeria is paraphyletic with respect to Asian Boehmeria, Cypholophus, American Boehmeria and B. depauperata, and polyphyletic with respect to $B$. nivea .

The selection of a single outgroup by Liang et al. (2020), comprising the most basal member of the Boehmerieae tribe, Oreocnide, meant that no effective test of monophyly was undertaken. Their resultant sectional classification combines distantly related taxa that only form a monophyletic group, with very low support, because of the application of an even more distantly related outgroup. In addition, in the presentation of their analyses of SNP data Liang et al. (2020) omit key details. For example, the filtering of homologous loci, a crucial step in the generation of phylogenetic trees from SNP data. In addition, the phylogenetic tree presented is based on neighbour-joining, rather than a maximum likelihood approach, and there seems no clear justification for this. Maximum likelihood approaches are accepted as more reliable for estimating relationships between taxa, than neighbour-joining (Holder \& Lewis 2003). Finally, the phylogenetic tree that they support has very low support values on most branches, less than 50\% in some cases, suggesting that they are poor predictions of relationships. Such low support values suggest strong incongruence or conflict within their data and that they have in fact recovered a large polytomy, rather than a resolved tree. That is, that many other groupings and relationships between groupings may be equally plausible, not a basis for a stable classification.

The most obvious risk of using this classification would be with respect to designing a crop breeding programme for ramie. The classification proposed by Liang et al. (2020) would suggest that, outside of Boehmeria nivea, the nearest relatives of ramie suitable for inclusion in a crop breeding programme would be from their sections, Siamensis, Duretia, Phyllostachys or Silvestri, whereas research published by Wu et al. $(2013,2018)$ suggests that populations of Archiboehmeria atrata are the nearest relatives of $B$. nivea. Using the classification of Liang et al. (2020) would, however, exclude this possibility.

We conclude that poor taxon sampling, a failure to consult the relevant molecular biology and taxonomic literature, internal conflict within their data and the over interpretation of low support values has resulted in the erroneous conclusion that Boehmeria represents a monophyletic or 'natural' genus and the presentation of an inaccurate estimate of relationships within Boehmeria, especially with respect to Boehmeria nivea, 'ramie'.

Acknowledgements We would link to thank Zeng-Yuan Wu for comments on the manuscript.

Funding This study received no financial support.

\section{Compliance with ethical standards}

Conflict of interest The authors declare that they have no conflict of interest.

Open Access This article is licensed under a Creative Commons Attribution 4.0 International License, which permits use, sharing, adaptation, distribution and reproduction in any medium or format, as long as you give appropriate credit to the original author(s) and the source, provide a link to the Creative Commons licence, and indicate if changes were made. The images or other third party material in this article are included in the article's Creative Commons licence, unless indicated otherwise in a credit line to the material. If material is not included in the article's Creative Commons licence and your intended use is not permitted by statutory regulation or exceeds the permitted use, you will need to obtain permission directly from the copyright holder. To view a copy of this licence, visit http://creativecommons.org/licenses/by/4.0/.

\section{References}

Chen CJ, Lin Q, Friis I, Wilmot-Dear CM, Monro AK (2003) Urticaceae. In: Wu Z, Raven P (eds) Flora of China, vol. 5. Science 
Press \& Missouri Botanical Garden Press, Beijing, St Louis, pp 76-189

Gaudichaud-Baupré C (1830) Botanique. In: De Freycinet ML, Voyage autour du monde, entrepris par ordre du roi. Exécuté sur les corvettes de S. M. l'Uranie et la Physicienne, pendant les années $1817,1818,1819$ et 1820 . Pillet-ainé, Paris

Holder M, Lewis PO (2003) Phylogeny estimation: traditional and Bayesian approaches. Nat Rev Genet 4:275-284

Kuntze O (1891) Revisio Generum Plantarum, pars 1-2. Felix, etc., Leipzig

Liang YK, Liu WC, Chen JH, Chen XR, Tang Q, Sun ZM, Luan MB (2020) Relationships among Chinese Boehmeria species and the evolution of various clade. Industr Crops Prod 148:112092. https ://doi.org/10.1016/j.indcrop.2020.112092

Linnaeus C (1753) Species Plantarum, vol. 2. Laurentius Salvius, Holmiae [Stockholm]

Plants of the World Online (2020) Royal Botanic Gardens, Kew. Available at: http://powo.science.kew.org/. Accessed 4 May 2020

Wilmot-Dear CM, Friis I (1996) The New World species of Boehmeria and Pouzolzia (Urticaceae, tribus Boehmerieae). A taxonomic revision. Opera Bot 129:1-103
Wilmot-Dear CM, Friis I (2013) The Old World species of Boehmeria and Pouzolzia (Urticaceae, tribus Boehmerieae). A taxonomic revision. Blumea 58:85-216

Wu ZY, Monro AK, Milne RI, Wang H, Yi TS, Liu J, Li DZ (2013) Molecular phylogeny of the nettle family (Urticaceae) inferred from multiple loci of three genomes and extensive generic sampling. Molec Phylogen Evol 69:814-827. https://doi. org/10.1016/j.ympev.2013.06.022

Wu ZY, Liu J, Provan J, Wang H, Chen CJ, Cadotte MW, Luo YH, Amorim BS, Li DZ, Milne RI (2018) Testing Darwin's transoceanic dispersal hypothesis for the inland nettle family (Urticaceae). Ecol Lett 21:1515-1529. https://doi.org/10.1111/ele.13132

Zhang B, Zheng CQ, Zhao LN, Zang GG (1998) The distribution and evaluation of Chinese wild relative species of ramie. China Seeds $16: 2-3$

Publisher's Note Springer Nature remains neutral with regard to jurisdictional claims in published maps and institutional affiliations. 